\title{
Utilizing the Corpus Approach in Developing EFL Writing Skills
}

\section{Dr. Eman Mohammed Abdel-Haq}

Professor of Curriculum and Instruction (EFL)

Faculty of Education, Benha University

Dr. Hossam Said Bayomy Ali

EFL Instructor, Faculty of Education,

Benha University

\section{Abstract:}

The aim of the present research was to investigate the
impact of utilizing the corpus approach on
developing EFL writing skills among student teachers. The participants of the study consisted of third year English section students enrolled in Faculty of Education, Benha University ( $N=23)$. The study followed the one-group pre-post test design. In addition, it was a mixed-research study including both quantitative and qualitative methods for collecting and analyzing the data in order to enhance the credibility of the research findings. The instruments of the present study were divided into two parts: (1) instruments used for quantitative analysis including: an EFL writing test and a rubric to score it and (2) instruments used for qualitative analysis including: a SemiStructured Interview (SSI), a Questionnaire of Corpus Use (QOCU) and an Evaluative Questionnaire (EQ). Furthermore, the researchers analyzed the essays and paragraphs written by the students as an assignment at the end of some sessions, in addition to self-reports written by the students about when and how they used the corpus in their writing. A Corpus-Based Program (CBP) was implemented to the participants during the second semester of the academic year 2014/2015. Results of both the quantitative and qualitative analysis revealed that the participants' EFL writing skills were developed significantly as a result of the CBP. Therefore, the corpus approach was recommended to be integrating into EFL writing instruction.

Key words: Corpus approach - EFL writing.

\subsection{Introduction:}

Within the field of foreign language teaching, the teaching of writing has come to assume a much more central position than it occupied twenty or thirty years ago. This is perhaps the result 
of two factors. On the one hand, command of good writing skills is increasingly seen as vital to equip learners for success in the 21 st century. On the other hand; writing has been identified as one of the essential process skills in a world that is more than ever driven by text and numerical data (Hyland, 2003: xiii). Further, Jahin (2012:60) stated that writing has become central in today's schools and universities as a measure for academic success. Moreover, writing encourages thinking and learning, motivates communication and makes thought available for reflection (Mekheimer, 2005). When thought is written down, ideas can be examined, reconsidered, superseded, rearranged and changed. The paramount importance of writing is further stated by Olshtain (2001:207) "...the skill of writing enjoys special status-it is via writing that a person can communicate a variety of messages to close or distant known or unknown readers".

Writing has always formed a part of the syllabus in the teaching of English. However, it can be used for a variety of purposes, ranging from being merely 'a backup' for grammar teaching to major syllabus strand in its own right, where mastering the ability to write effectively is seen as a key objective for the learner (Harmer, 2004). Moreover, Zhu (2004) added that writing is an important productive skill that can be used in learning other receptive and productive skills. Moreover, writing is among the most important skills that EFL students need to develop, and the ability to teach writing is central to the expertise of a well-trained language teacher. Similarly, DeDeyn (2011) stated that writing is a language skill essential for academic success and a skill required in many occupations.

In addition, Eggenschwiler and Biggs (2001) stated that effective writing is an essential communication skill that is necessary in personal relationships and in almost every profession. Therefore, writing has always been regarded as an important skill contributing to students' language learning. The importance is exasperated when we consider that in almost every course there is a writing element of some kind. Moreover, 
in almost all schools and universities in many EFL countries (including Egypt) students' academic success in EFL courses is measured, to a large extent, depending on their final written product. This is because the educational systems in these countries adopted product-oriented philosophies. Therefore, some students, despite their excellence, may score low on written tests because they lack the necessary EFL writing skills required for expressing their ideas clearly.

However, for many EFL learners, writing is generally regarded as a difficult skill and a complex task because writers should balance multiple issues, such as content, organization, purpose, audience, vocabulary, punctuation, spelling and mechanics (Zacharias, 2007). Moreover, writing clearly takes more effort and it can be a more intimidating experience. Many eloquent and articulate speakers go to great lengths to avoid placing their thoughts in writing, because the written word is permanent and allows the reader time to analyze and assess (Sova, 2004:1). Further, Erkan and Saban (2011:164-165) added that since it is an active, productive skill, students learning to write in a foreign language face multiple challenges. For this group, writing requires thinking strategies that allow the individual to express him or herself competently in the other language, and is a complex activity that requires a certain level of linguistics knowledge, writing conventions, vocabulary and grammar.

On the same vein, Cumming (2006:473) argued that writing is a profoundly complex ability, a highly conventionalized mode of communication, and a uniquely personal form of individual expression. Helping students to improve their writing requires an approach to teaching that attends to each of these elements judiciously. At the same time, teachers need to foster students' capacities to regulate their own writing performance autonomously, purposefully, and effectively. Therefore, there have been many attempts aimed to help students improve their writing skill and increase their motivation for accomplishing the writing tasks. Because, as Shang (2013b) stated, a high command 
of EFL writing skills is critical to enhance students' writing performance and academic success.

With respect to the nature of EFL writing, previous research has asserted that writing is a continuous process of discovering how to find the most effective language for communicating one's thoughts and feelings. Its importance lies in enhancing language acquisition, as learners experiment with words, sentences and large chunks of writing to communicate their ideas effectively and reinforce the grammar and vocabulary they are learning in class. In addition, it is the stage where thought transformed into print. Thus, students should master the written form of language and learn certain structures, which are important for effective communication in writing (Abdel-Hack, 2002, 2009; Abdel-Maksoud, 2007; El-Marsafy, 2009;Helwa, 2013).

Due to the increased emphasis on EFL writing skills, a great number of previous studies have been conducted to develop these skills using various approaches and strategies; one of these approaches that has gained prominent importance recently is technology due to the increased emphasis on its effect on EFL teaching and learning in general and on EFL writing in particular.

Recently, technology has had a massive impact on almost every facet of our life, and EFL learning and teaching in general. Breyer (2009) maintained that "the advent of computers has brought about significant changes to the study of language. In fact, the concept of language, the way it is studied and what exactly it is have changed dramatically since computer technologies have become widely available to the research community". Recently, computers have become powerful tools and important resources in the area of literacy (reading and writing). Technology is found to enhance better teaching and learning environments. A number of researchers (Finn \& Inman, 2004; San, 2007; Kiser \& Craven, 2009) ascertain that utilizing computers in classrooms has shown to have a positive impact on educational outcomes, especially students' performance. 
Previous research (Lee, 2000b; Paulus \& Nakamichi, 2002; Tsou; Wang \& Li, 2002; Gömleksiz, 2004) stated that when integrated appropriately, technologies can: support experiential learning, practice in a variety of modes, provide effective feedback to learners, enable pair and group work, promote exploratory and global learning, enhance student achievement, provide access to authentic materials, facilitate greater interaction, individualize instruction, allow independence from a single source of information, motivate learners, help education system work better and more effectively, enhance students' reading, writing and thinking skills, provide support for intensive/extensive reading/writing activities, increase the effectiveness of language classrooms than it used to be and give students the chance of learning faster and more permanent.

To sum as an educational tool, technology finds a number of applications in and outside the classroom. Many researchers (Kiser \& Craven, 2009; Yanguas, 2009; Noytim, 2010; Alshumaimeri, 2011; Yang \& Meng, 2013) observed that the development of online technologies has brought new ways of learning and teaching.

Specifically, technology has had a massive impact on EFL classrooms over the last decade or so and writing instruction now makes considerable use of computer technologies. Some teachers have welcomed these developments enthusiastically, seeing the integration of new technology as a means of enlivening instruction and improving students' writing skills. Accordingly, the pressure on teachers to take up technology is becoming increasingly difficult to resist (Hyland, 2003:143). Moreover, the emergence of technology has greatly contributed to the shift in teaching writing. It has created more effective opportunities for EFL learners to improve these skills. Therefore, teachers and students are expected to develop their computer literacy and use technology for teaching and learning writing (Ismail; Al-Awidi \& Almekhlafi, 2012).

Pennington (2003) adopted the strong position maintaining that "those charged with instructing EFL students in 
writing cannot afford to remain outside these developments ..., teachers should be prepared to bring computers into the center of their own pedagogical practice". Similarly, Mozaheb; Seifoori and Beigi (2013) added that the use of technology for teaching writing is another important circle that is lost in the age of the Internet and different communication tools, such as Facebook, Twitter and Wikis. Thus, students may have the chance to improve their writing skill with the technological opportunities more easily than the way they traditionally do. Accordingly, the use of different technologies in writing classes has been mentioned in a number of research studies, including: Elola \& Oskioz, (2010); Miyazoe \& Anderson (2010); Fageeh (2011); Kutlu, (2013).

Specifically, the ability to store language data on computer systems and gain access to them through a software interface has paved the way for the emergence of modern corpus linguistics (CL) approach. The main subject of inquiry of this approach is language data stored in digital format and its most powerful tool of analysis is the "concordance" (Breyer, 2009). In addition, Nam (2010) stated that the applications of CL approaches have been widely accepted in language teaching and research since these applications have widened the perspectives in EFL education for teaching vocabulary, grammar, reading, and writing.

There are many benefits to be gained from introducing students to corpora. The most important is to allow students to encounter 'real language' rather than made-up examples. Also form-meaning links can be taught in order to minimize the learning load and EFL learner can use corpus evidence to help develop individual creativity in language use. In addition, corpuslinguistic methods support exploratory and discovery learning which encourages autonomous learning and teaching. Also, corpora can capture reality and provide valid models for learners (Bernardini, 2004; Braun, 2005, Granath, 2009).

The corpus approach has made its way into the language classroom where its presence ranges from the presentation of printed concordance data with accompanying tasks to the direct 
use of concordancing software by learners themselves to carry out analyses of self-selected language features. In addition, corpora are invaluable for teachers, in that they can employ them in a number of ways: to create exercises, demonstrate variation in grammar, show how syntactic structures are used to signal differences in meaning and level of style, discuss near-synonyms and collocations, and to give informed answers to student questions. Further, Johansson (2004) stated that corpora have many applications which are relevant to language teaching. They can be used in the preparation of textbooks, grammars, dictionaries and other teaching material. They can also be used in syllabus design, in the training of teachers, in testing and in the classroom.

The word "corpus" (plural corpora) originates from a Latin word meaning "body". In linguistic terms, a corpus is "a large collection of naturally occurring texts gathered from users of the English language, both spoken and written, containing thousands or millions of words, stored for the purposes of language study in an electronic database (Thornbury, 2010). In addition, Garner and Nelson (2011:2) stated that "a corpus is a large body of realworld texts collected and analyzed by linguists to study actual language in use". This could refer to a collection of simple sentences, written texts, oral interviews, or any other pieces of language in use that are stored and accessed electronically". Redrupová (2009) stated that these databases can either be accessed via the internet or can be installed and accessed locally on a computer.

Moreover, Samburskiy (2014) maintained that CL analysis is different from other approaches in that it offers a rigorous inductive approach to language inquiry, which allows for quantification of authentic language patterns. Moreover, CL revealed an intricate interplay between form and meaning, thus promoting a fresh stance on language pedagogy labeled lexicogrammar which considers lexicon and grammar to be generally intertwined, forming a single entity with no distinction between form and meaning. In addition, CL provides user- 
friendly tools that could be easily incorporated into classroom activities or used independently at home.

Carter and McCarthy (1995:155) referred to the difference between the corpus approach and traditional approaches to language teaching as follows: with the corpus-based approach to language pedagogy, the traditional "three Ps" (Presentation, Practice and Production) approach to teaching may not be entirely suitable. Instead, the more exploratory approach of "three Is" (Illustration, Interaction and Induction) may be more appropriate, where "illustration" means looking at real data, "interaction" means discussing and sharing opinions and observations, and "induction" means making one's own rule for a particular feature, which "will be refined and honed as more and more data is encountered".

On the other hand, previous research (Hyland, 2006; O'Sullivan \& Chambers, 2006; Balunda, 2009; Granath, 2009; Nam, 2010) has indicated that there are many benefits to be gained from introducing students to corpora; these include:

- allow students to encounter 'real language' rather than made-up examples;

- corpora are particularly suited to pursuing constructivist principles which provide strong support for the contention that effective learning begins from the learner's active participation in the process of learning;

- corpus consultation fits well with the theories surrounding process-oriented instruction, as the corpus provides the resources and tools needed for learners to build their own knowledge while developing their cognitive and metacognitive processes;

- consulting a corpus allows learners to correct their errors inductively;

- corpus consultation enhances learner autonomy;

- students benefit more from a "learning by discovery" approach tailored by corpus approach since this encourages learners to follow their own interests; 
- not only does the corpus provide an open-ended supply of language data tailored to the learner's needs, but also promotes a learner-centered approach bringing flexibility of time and place;

- the corpus can radically change classrooms; the classroom become more individualized and student-centered;

- corpus exercises can be used to vary classroom tasks, and examples of authentic language use can give students a much more vivid picture of the language than reference books;

- the corpus involves both inductive and deductive learning strategies; therefore, advantages of both learning strategies are combined.

- the data provided by corpus is: realistic, showing language in real use; rich, providing more diversified information than dictionaries or reference grammars; illustrative, providing actual patterns of use instead of abstract explanations and up-to-date, revealing trends in language use and evidence for short-term historical change.

In spite of the above mentioned advantages of corpus, there are some limitations of the approach. Some of these limitations concern the very approach itself; other limitations relate to the implementation of the corpus either by the teacher or by the students themselves. However, this has not and will not detract from the need for its integration in EFL learning and teaching (Farr, 2008:28). Researchers (Godwin-Jones, 2001; Hunston, 2002;Yoon \& Hirvela, 2004) have stated some of these limitations or obstacles in the process of using corpus linguistics as follows:

- users need to be reasonably familiar with aspects of statistics, text encoding and computer applications, which can put some people off initially;

- data collection can be more time consuming and requires more; 
- lexical information may be vast and confusing to learners;

- the contexts are rich, varied and plentiful but they are also short, incomplete, and do not form a coherent whole ;

- not all learners may have equally positive attitudes towards inductive discovery learning ;

- some learners may have difficulty in acquiring the skills needed to experience corpus;

- corpora can tell whether something is frequent, or not, but they are not able to tell if something is possible in a language;

- corpora can only show what they contain; and

- corpora can give evidence but the user must then interpret this information.

Nonetheless, despite these limitations, the advantages of corpus linguistics outweigh the limitations and, as O'Keeffe and McCarthy (2010:12) stated, corpus linguistics is 'a healthy, vibrant discipline'. The key to its success remains the same basic method: 'large quantities of "raw" text are processed directly in order to present the researcher with objective evidence'.

It can be concluded therefore that corpus affects many aspects of the teaching and learning process taking place within the EFL classroom. Generally, bringing corpus data into the classroom has brought many challenges over the years. By its nature, it turns the traditional order within the classroom upon its head. The corpus becomes the centre of knowledge, the students take on the role of questioner and the teacher is challenged to hand over control and facilitate learning. Specifically, Chambers and 0'Sullivan (2004) have shown the democratizing effect of devolving the correction and remediation of student writing through the use of error tagging and follow-up student corpus investigation. Accordingly, the use of corpus data has become increasingly appealing in the context of EFL writing instruction, where the simultaneous focus on vocabulary, grammar, and discourse patterns provides EFL writers with the 
kinds of target language input they especially need to achieve high levels of proficiency as EFL writers.

Similarly, the use of CL and concordancing offer one of the most exciting applications of new technologies to the writing class, providing teachers with evidence of language use not available from other sources. Electronic corpora are becoming increasingly important in EFL writing instruction as teaching becomes less a practice of imparting knowledge and more one of providing opportunities for learning (Hyland, 2003). Therefore, including corpus in a writing syllabus encourages or enhances inductive language learning, an important feature of EFL acquisition. The result is student-centered discovery learning, which promotes self-confidence and mastery of the learning process.

Based on such benefits of corpora use in EFL writing, many studies (Gaskell \& Cobb, 2004; Yoon \& Hirvela, 2004; Koosha \& Jafarpour, 2006; Charles, 2007; Yeh; Liou \& Li, 2007; Yoon, 2008; Nam, 2010 and Saunders, 2010) have argued for the inclusion of corpora in teaching materials and classroom activities. This is not a call for a corpus-dominated writing pedagogy, but rather the inclusion of some corpus-based activity with respect to treating the language side of L2 writing.

With regard to the relationship between EFL writing and CL, many researchers pointed out that corpus is useful in developing students' writing skills. For example, in a study of students' behavior when using a corpus, and their perceptions of the strengths and weaknesses of corpora as an EFL writing tool, Yoon and Hirvela (2004) found that the students generally perceived the corpus approach to be beneficial for the development of EFL writing skills and increased their confidence in EFL writing. In a similar study, Nam (2010) investigated how corpus-based language learning helped EFL learners develop their productive vocabulary knowledge in writing. The results indicated that there were recognizable differences in the ESL writing quality between the groups in that the concordancer 
group gained more grammatical knowledge than the thesaurus group.

Furthermore, Yoon (2005) examined the quality of students' writing experiences with corpus use, how it affects their development of EFL competence, and most importantly, how corpus technology can be integrated into EFL writing instruction. The results indicated that as the corpus approach was introduced and linked to the writing process, the students become more independent writers through increased access to linguistic resources. By doing so, they approached EFL writing with more ease, and their overall confidence in writing increased. Similarly, in a longitudinal study in which learners focused on their own data, Chambers and O'Sullivan (2004) stress the importance of 'corpus consultation' as a means of improving writing.

Moreover, Tseng and Liou (2006) examined the effect of online conjunction materials plus authentic examples from corpus-based concordancing on EFL college students' overall writing quality. The results indicated that online conjunction materials plus authentic examples from corpus-based concordancing helped college EFL learners write more accurate and appropriate essays. In a similar study, Yoon (2008) examined how corpus technology affects students' development of competence as EFL writers. The findings revealed that corpus use not only had an immediate effect by helping the students solve immediate writing/language problems, but also promoted their perceptions of lexico-grammar and language awareness. Yoon added that once the corpus approach was introduced to the writing process, the students assumed more responsibility for their writing and became more independent writers, and their confidence in writing increased.

Moreover, the results of a survey by Römer (2009) showed that $88 \%$ of non-native teacher participants thought that they needed the advice of a native speaker to help with the correction of class tests and student writings. Also, students would often like to check with native speakers about whether or not their 
writing is acceptable. However, not only are native speakers not always available, but also even native speakers do not always know the correct answer. Accordingly, Kim (2009) argued that the use of a searchable data corpus provides an excellent resource for EFL students and teachers in these situations.

Practically, corpora have principally been used in two main ways to inform writing instruction, either through a corpusbased approach where worksheet materials are derived from concordance output, or through a corpus-driven approach, commonly referred to as data-driven learning (DDL), which requires the student to interact directly with the corpus. It should be pointed out that in reality many writing instruction programs utilize a combination of these two approaches, although the corpus-driven approach is far more prevalent. Moreover, corpora have been exploited at different stages of the writing process from initial drafting through to the final proofreading and editing stages (Flowerdew, 1998).

On the same vein, Hyland (2003) pointed out that taken together, corpora and concordancing in the EFL writing class can serve as research tools (or DDL tools) that help learners to discover underlying rules and regularities from the given concordance data and to raise their language awareness on the one hand. For example, Cresswell (2007) investigated the effects of corpus-based DDL on the use of connectors in an EFL academic writing course at an Italian university. The students were divided into a DDL group and a non-DDL group. The students in the DDL group used a concordancer to investigate meaning, usage, and syntactic patterns of English logical connectors in corpora while the non-DDL group followed the course without concordance consultation. Results indicated that the DDL group presented inductively derived descriptions that were relatively accurate.

On the other hand, the corpus can be used as reference tools that learners can consult when they encounter problems in writing along with or instead of traditional reference resources such as dictionaries and grammar books on the other. For 
example, Gaskell and Cobb (2004) investigated how EFL writers use concordance feedback to correct their sentence-level writing errors. Moreover, Chambers and O'Sullivan (2004) and O'Sullivan and Chambers (2006) conducted a two-phase research project involving native English speaking learners of French at different levels of writing proficiency in Ireland. The participants were given the opportunity to improve their writing skills using a small semi-specialized corpus to investigate how effectively they make changes in their writing and how they evaluate the process of corpus consultation.

In the light of such benefits of corpora use in EFL writing, many studies have argued for the inclusion of corpora in teaching materials and classroom activities. This is not a call for a corpus-dominated writing pedagogy, but rather the inclusion of some corpus-based activity with respect to treating the language side of EFL writing (Yoon \& Hirvela, 2004:259). For example, Koo (2006) tested the effects of using corpora and online concordancing tools on EFL writing among Korean graduate students $(\mathrm{N}=10)$.The results indicated that by using the concordancing program, learners gained confidence as EFL writers as they had inside access to linguistic resources. Moreover, the subjects became more independent and were able to solve their own writing and linguistic problems as they became more aware through the use of authentic texts. The same findings were asserted by similar studies such as: (Yoon, 2005; Tseng \& Liou, 2006; Yeh; Liou \& Li, 2007).

Corpus can also be used not only in developing EFL writing skills, but some authors used it in analyzing students' writing. For example, Wen-juan and Hong-bo (2011) used corpus to discriminate between scientific writing and creative writing in academic contexts. Similarly, Crompton (2005) used a corpusbased approach to analyze the use of the word where in texts written by Malay-speaking learners of English. Data from a leaner corpus is compared with data from two corpora of academic writing by native English-speaker writers. Considerable over-use of where was found. 
After reviewing literature and related studies both in the field of EFL writing and corpus linguistics (CL), it is now clear that the relationship between the two is clear and logic; i.e. previous research has asserted that CL has a significant effect on developing EFL writing skills.

\subsection{Context of the problem:}

In spite of the importance of EFL writing skills and the need for developing such skills, EFL learners generally and EFL Egyptian learners in particular suffer from a lack of these skills. Previous studies (Abdel-Maksoud, 2007; El-Serafy, 2008; AbdelHack, 2009a; El-Marsafy, 2009, Helwa, 2013) have attributed this lack to many factors; some of which were related to the learner himself; these include students' limited background knowledge, lack of motivation to write, fear of negative evaluation from their peers or teachers, etc. Other factors were attributed to the teacher, for example, some teachers adopt authoritative, teachercentered, product-based model of teaching writing. Thirdly, the learning environment can be the cause, in that some learning environments are stressful, anxiety-evoking and less encouraging. In addition, other researchers attributed this lack to the traditional instructional practices adopted by many educators. To make sure of this lack of EFL writing skills, the researcher conducted a pilot study on third year English section students at the Faculty of Education, Benha University. The participants consisted of (34) students. The researcher used an EFL writing test to assess the students' EFL writing skills. The results indicated that there is a lack of the basic skills of writing among those students and this was clear in their improper use of vocabulary, a lot of grammatical mistakes, lack of the basic organization features, structure, incoherence of ideas and there were many punctuation and spelling errors.

\subsection{Statement of the problem:}

The problem of the present research lies in that third year English section students lack EFL writing skills.

\subsection{Questions:}

The present study attempted to answer the following questions: 
a. What are the EFL writing skills required for student teachers?

b. What are the features of the Corpus-Based Program (CBP)?

c. What is the effectiveness of the CBP in developing EFL writing skills among student teachers?

\subsection{Design:}

The present study follows the one-group pre-post test design (figure, 1 ) to investigate the validity of the Corpus-Based Program (CBP) in developing student teachers' EFL writing skills and reducing their EFL writing anxiety.

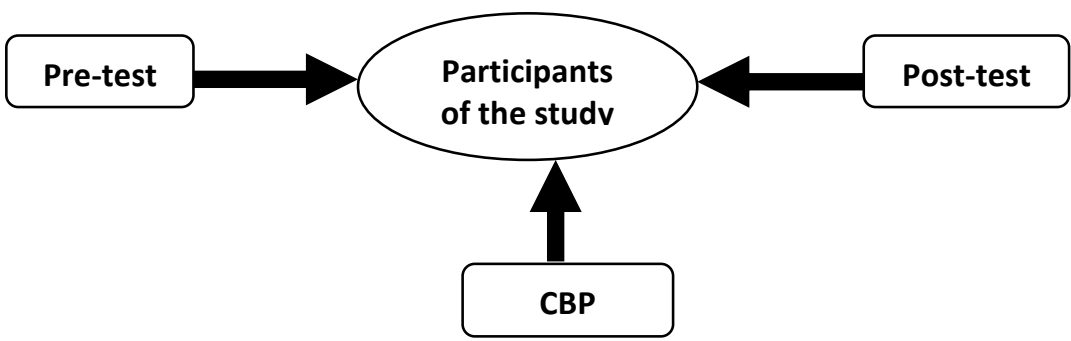

Figure (1): The Design of the Study

The present study can also be classified as"a mixedmethod" study; uses both quantitative and qualitative data to answer a particular question or set of questions" to: enhance the credibility of the research findings, gain a fuller understanding of the research problem and clarify a given research result.

\subsection{Participants:}

The participants of the present research consisted of third year English section students enrolled in Benha Faculty of Education during the academic year 2014/2015. The final sample of the study was (23) students who attended almost all the sessions of the program and the pre- and post-applications of the instruments of the study. For the qualitative analysis, ten students were chosen from the (23) students based on their scores on the EFL writing test (the highest five scores and the lowest five).

\subsection{Instruments and materials:}

The researchers developed and used the following instruments and materials to determine quantitatively and 
qualitatively the impact of the utilizing the corpus approach in developing student teachers' EFL writing skills. For the quantitative analysis, the researchers developed the following instruments.

1. An EFL Writing Test (used pre and post) to measure student teachers' EFL writing skills and a rubric to score and analyze students' performance on the EFL wiring skills test.

For the qualitative analysis the following instruments were developed:

1. A Semi-Structured Interview (SSI) administered individually to (10) students before and after implementing the CBP to get a clear picture of the students' EFL writing skills before and after implementing the program.

2. A Questionnaire of Corpus Use (QOCU) to identify the students' opinions of the corpus and how it was helpful in developing their EFL writing skills.

3. An Evaluative Questionnaire (EV) of the CBP to investigate students' opinions and attitudes toward the CBP.

4. Document analysis, including the essays and paragraphs written by the students as an assignment at the end of some sessions, in addition to self-reports written by the students about when and how they used the corpus in their writing.

5. Reflective notes, taken by the researchers during and after each session of the CBP.

\subsection{Procedures of the study}

The researchers followed the following procedures to fulfill the purpose of the present study:

1. Identifying the EFL writing skills required for EFL student teachers through: 
a. Reviewing literature, writing courses specifications, national standards for teachers' preparation programs and previous studies related to EFL writing skills.

b. Preparing a list of EFL writing skills required for third year English section students.

c. Submitting this list to a jury to verify its validity.

d. Modifying and setting the list in its final form according to the jury's suggestions.

2. Identifying the features of the Corpus-Based Program (CBP) through:

a. Reviewing literature and previous studies related to both corpus linguistics and EFL writing skills.

b. Identifying the objectives, content, activities, roles of the researchers and students and evaluation techniques that will be used in the program.

c. Designing the instruments of the study.

d. Submitting the instruments to a panel of jury members to verify its validity.

e. Modifying and setting the instruments in its final form according to the jury's suggestions.

3. Identifying the effectiveness of the CBP in developing student teachers' EFL writing skills through:

a. Assigning a sample of third year English section students into one group.

b. Administering the EFL writing skills test to the participants of study (pre-test).

c. Selecting ten students from the participants of study (the highest " 5 " and lowest "5" scores on the EFL writing test for qualitative analysis.

d. Administering a Semi-Structured Interview (SSI) to the ten students before the program (preassessment).

e. Implementing the CBP to the participants of study. 
f.Administering the EFL writing test to the participants of research after implementing the CBP (post-test).

g. Administering the SSI to the ten students after the program (post-assessment).

h. Administering the EV and the QOCU to the participants of research after the CBP.

i. Comparing the results statistically.

j. Analyzing the results of the research quantitatively.

$\mathrm{k}$. Analyzing the results of the research qualitatively.

l. Interpreting the results of the research.

m. Providing recommendations and suggestions for further research.

\subsection{Definition of Terminology:}

\section{EFL writing skills:}

Bello (1997) defined it as "a continuing process of discovering how to find the most effective language for communicating one's thoughts and feelings".

Fulwiler (2002:3) provided the following definition of EFL writing skills "processes needed to produce good writing exemplified in correct grammar, range of vocabulary, accurate punctuation, correct layout, accurate spelling and good range of sentence structure. It involves making choices about topics, approaches, stances, claims, evidence, order, words, sentences, paragraphs, tone, voice, style, titles, beginnings, middles, endings, what to include, what to omit, etc. In other words, the purpose, situation, and audience determine the tone, style, and form of writing".

Based on these definitions, the researchers adopted the following definition: EFL writing skills can be defined as "skills required for producing a piece of writing including: fluency, accuracy (grammar and word choice), content, organization, stylistic, mechanics and revision skills".

\section{Corpus:}

Is a large collection of naturally occurring texts gathered from users of the English language, both spoken and written, 
containing thousands or millions of words, stored for the purposes of language study in an electronic database (Thornbury, 2010).

\section{Corpus linguistics:}

Is the study of linguistic phenomena by means of a set of investigative tools such as corpora and concordancing programs. Its main features include computational techniques and a large collection of language samples in the form of written or transcribed spoken language (Koo, 2006:8).

\subsection{Results and Discussion:}

\subsubsection{Findings of the quantitative analysis of the study:}

The data of the present study were statistically analyzed using the Statistical Package for Social Sciences (SPSS, v.15) program. The findings of the present study indicated that "there is statistically significant difference between the pre and the post mean scores of the participants of the present study in the overall EFL writing skills, in favor of the post-assessment". Table (1) presents the students' mean scores, standard deviations, tvalue and level of significance of the experimental group in the pre- and post-assessment in the overall EFL writing skills where t-value is (37.77) which is significant at the (0.01) level of significance.

Table (1): Results of " $t$ " test between the pre and the post mean scores of the participants of the present study in the overall EFL writing skills.

\begin{tabular}{|l|l|l|l|l|l|l|l|}
\hline Skill & Application & N & Mean & S.D & $\begin{array}{l}\text { T- } \\
\text { value }\end{array}$ & D.F & Sig. \\
\hline \multirow{2}{*}{$\begin{array}{l}\text { EFL } \\
\text { writing }\end{array}$} & Pre- & 23 & 43.3913 & 4.30369 & 37.770 & 22 & .01 \\
\cline { 2 - 8 } & Post- & 23 & 60.0870 & 3.52798 & 3 & \\
\hline
\end{tabular}

These findings can be presented graphically by the following graph. 


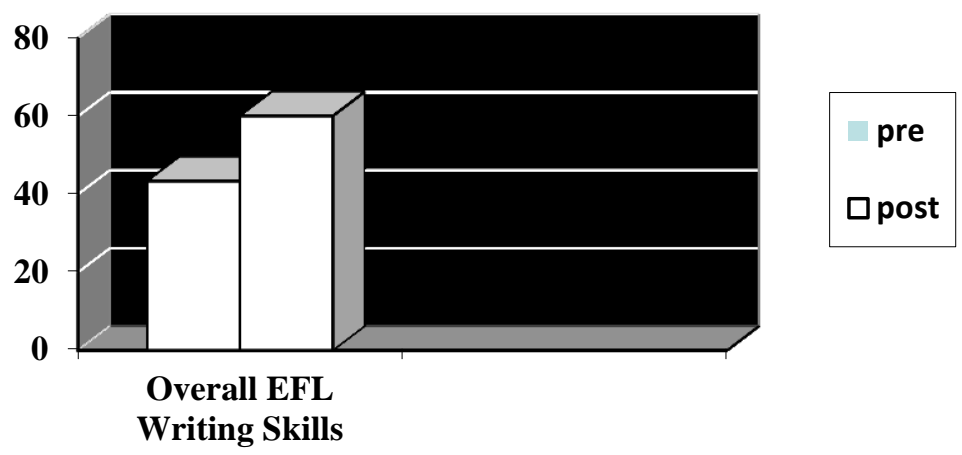

Figure (2): The mean scores of the pre and post assessment of the overall EFL writing skills of the participants of the study

\subsubsection{Findings of the qualitative analysis:}

\section{A. Findings of the Semi-Structured Interview (SSI):}

A semi-structured interview (appendix, ) was used to get a more detailed picture of the students' writing skills before the experiment and how these skills developed as a result of implementing the CBP. From the students' answers to the questions of the interview, their answers were qualitatively analyzed and the following results were obtained: before the experiment most of the students' answers indicated that these students lacked the necessary knowledge of EFL writing regarding its meaning and importance to them as EFL prospective teachers. They even indicated ignorance of the writing sub-skills and the writing stages that the writer goes through to produce an essay.

\section{B. Findings of the Questionnaire of Corpus Use (QOCU):}

After implementing the CBP, the QOCU was applied to the participants of the present study to investigate their opinions of the corpus and how it was helpful in developing their EFL writing skills. The results of analyzing the questionnaire indicated that the CBP was effective in developing these skills. Table (2) indicated these results as follows: 
Table (2): The Results of the Students' Responses to the QOCU

\begin{tabular}{|c|c|c|c|c|c|c|}
\hline Statement & SA & A & D & SD & N/A & $\begin{array}{c}\text { No } \\
\text { response }\end{array}$ \\
\hline $\begin{array}{c}\text { Using the corpus helped me } \\
\text { brainstorm to get as many } \\
\text { ideas as possible about the } \\
\text { topic. }\end{array}$ & $\begin{array}{c}2 \\
8.69 \\
\%\end{array}$ & $\begin{array}{c}19 \\
82.6 \%\end{array}$ & $\begin{array}{c}\mathbf{0} \\
0 \%\end{array}$ & $\begin{array}{c}\mathbf{0} \\
0 \%\end{array}$ & $\begin{array}{c}\mathbf{0} \\
\mathbf{0} \%\end{array}$ & $\begin{array}{c}2 \\
8.69 \%\end{array}$ \\
\hline $\begin{array}{l}\text { Using the corpus helped me } \\
\text { identify the main ideas and } \\
\text { supporting details about a } \\
\text { given topic. }\end{array}$ & $\begin{array}{c}2 \\
8.69 \\
\%\end{array}$ & $\begin{array}{c}18 \\
78.2 \%\end{array}$ & $\begin{array}{c}1 \\
4.3 \%\end{array}$ & $\begin{array}{c}0 \\
0 \%\end{array}$ & $\begin{array}{l}2 \\
8.69 \\
\%\end{array}$ & $\begin{array}{c}0 \\
0 \%\end{array}$ \\
\hline $\begin{array}{l}\text { Using the corpus helped me } \\
\text { decode the instructions to } \\
\text { determine what to write } \\
\text { about the topic. }\end{array}$ & $\begin{array}{l}1 \\
4.3 \\
\%\end{array}$ & $\begin{array}{c}11 \\
47.82 \\
\%\end{array}$ & $\begin{array}{c}3 \\
13.04 \\
\%\end{array}$ & $\begin{array}{c}\mathbf{0} \\
0 \%\end{array}$ & $\begin{array}{l}7 \\
30.4 \\
\%\end{array}$ & $\begin{array}{c}1 \\
4.3 \%\end{array}$ \\
\hline $\begin{array}{l}\text { Using the corpus helped me } \\
\text { use the language } \\
\text { spontaneously, continuously } \\
\text { and fluently in writing. }\end{array}$ & $\begin{array}{c}2 \\
8.69 \\
\%\end{array}$ & $\begin{array}{l}15 \\
65.21 \\
\%\end{array}$ & $\begin{array}{c}2 \\
8.69 \\
\%\end{array}$ & $\begin{array}{c}1 \\
4.3 \%\end{array}$ & $\begin{array}{l}1 \\
4.3 \\
\%\end{array}$ & $\begin{array}{c}2 \\
8.69 \%\end{array}$ \\
\hline $\begin{array}{l}\text { Using the corpus helped me } \\
\text { express ideas and opinions on } \\
\text { a variety of topics. }\end{array}$ & $\begin{array}{c}4 \\
17.3 \\
9 \%\end{array}$ & $\begin{array}{c}13 \\
56.52 \\
\%\end{array}$ & $\begin{array}{c}3 \\
13.04 \\
\%\end{array}$ & $\begin{array}{c}0 \\
0 \%\end{array}$ & $\begin{array}{c}2 \\
8.69 \\
\%\end{array}$ & $\begin{array}{c}1 \\
4.3 \%\end{array}$ \\
\hline $\begin{array}{l}\text { Using the corpus helped me } \\
\text { write grammatically correct } \\
\text { sentences. }\end{array}$ & $\begin{array}{c}2 \\
8.69 \\
\%\end{array}$ & $\begin{array}{c}20 \\
86.95 \\
\%\end{array}$ & $\begin{array}{c}1 \\
4.3 \%\end{array}$ & $\begin{array}{c}\mathbf{0} \\
0 \%\end{array}$ & $\begin{array}{c}\mathbf{0} \\
\mathbf{0} \%\end{array}$ & $\begin{array}{c}0 \\
0 \%\end{array}$ \\
\hline $\begin{array}{l}\text { Using the corpus helped me } \\
\text { use a variety of vocabulary } \\
\text { appropriate to the topic of the } \\
\text { essay. }\end{array}$ & $\begin{array}{c}2 \\
8.69 \\
\%\end{array}$ & $\begin{array}{c}19 \\
82.6 \%\end{array}$ & $\begin{array}{c}1 \\
4.3 \%\end{array}$ & $\begin{array}{c}0 \\
0 \%\end{array}$ & $\begin{array}{l}1 \\
4.3 \\
\%\end{array}$ & $\begin{array}{c}0 \\
0 \%\end{array}$ \\
\hline $\begin{array}{l}\text { Using the corpus helped me } \\
\text { write an essay that contains } \\
\text { one main idea or point of } \\
\text { view. }\end{array}$ & $\begin{array}{l}1 \\
4.3 \\
\%\end{array}$ & $\begin{array}{c}16 \\
69.56\end{array}$ & $\begin{array}{c}2 \\
8.69 \\
\%\end{array}$ & $\begin{array}{c}1 \\
4.3 \%\end{array}$ & $\begin{array}{c}3 \\
13.0 \\
4 \%\end{array}$ & $\begin{array}{c}0 \\
0 \%\end{array}$ \\
\hline $\begin{array}{l}\text { Using the corpus helped me } \\
\text { write relevant and enough } \\
\text { details that support the main } \\
\text { idea and avoid irrelevant } \\
\text { ideas. }\end{array}$ & $\begin{array}{c}5 \\
21.7 \\
\%\end{array}$ & $\begin{array}{c}13 \\
56.52 \\
\%\end{array}$ & $\begin{array}{c}2 \\
8.69 \\
\%\end{array}$ & $\begin{array}{c}1 \\
4.3 \%\end{array}$ & $\begin{array}{c}2 \\
8.69 \\
\%\end{array}$ & $\begin{array}{c}0 \\
0 \%\end{array}$ \\
\hline $\begin{array}{l}\text { Using the corpus helped me } \\
\text { write logically sequenced } \\
\text { sentences related to the main } \\
\text { idea of the essay. }\end{array}$ & $\begin{array}{c}2 \\
8.69 \\
\%\end{array}$ & $\begin{array}{c}15 \\
65.21 \\
\%\end{array}$ & $\begin{array}{c}1 \\
4.3 \%\end{array}$ & $\begin{array}{c}2 \\
8.69 \\
\%\end{array}$ & $\begin{array}{c}2 \\
8.69 \\
\%\end{array}$ & $\begin{array}{c}1 \\
4.3 \%\end{array}$ \\
\hline $\begin{array}{c}\text { Using the corpus helped me } \\
\text { use suitable transitions, } \\
\text { logical connectors and } \\
\text { adequate coherence markers } \\
\text { for ensuring smooth flow and } \\
\text { sequence of ideas. }\end{array}$ & $\begin{array}{c}1 \\
4.3 \\
\%\end{array}$ & $\begin{array}{c}17 \\
73.91 \\
\%\end{array}$ & $\begin{array}{c}2 \\
8.69 \\
\%\end{array}$ & $\begin{array}{c}\mathbf{0} \\
0 \%\end{array}$ & $\begin{array}{c}2 \\
8.69 \\
\%\end{array}$ & $\begin{array}{c}1 \\
4.3 \%\end{array}$ \\
\hline $\begin{array}{l}\text { Using the corpus helped me } \\
\text { clarify the meaning by } \\
\text { applying comprehensibility- } \\
\text { enhancing strategies such as } \\
\text { rephrasing, summarizing, } \\
\text { emphasizing key ideas; etc... }\end{array}$ & $\begin{array}{c}\mathbf{0} \\
\mathbf{0} \%\end{array}$ & $\begin{array}{c}14 \\
60.86 \\
\%\end{array}$ & $\begin{array}{c}4 \\
17.39 \\
\%\end{array}$ & $\begin{array}{c}1 \\
4.3 \%\end{array}$ & $\begin{array}{c}2 \\
8.69 \\
\%\end{array}$ & $\begin{array}{c}2 \\
8.69 \%\end{array}$ \\
\hline $\begin{array}{l}\text { Using the corpus helped me } \\
\text { set the introduction, body and } \\
\text { conclusion of the essay } \\
\text { clearly. }\end{array}$ & $\begin{array}{c}\mathbf{0} \\
\mathbf{0} \%\end{array}$ & $\begin{array}{c}6 \\
26.08 \\
\%\end{array}$ & $\begin{array}{c}7 \\
30.43 \\
\%\end{array}$ & $\begin{array}{c}6 \\
26.0 \\
\%\end{array}$ & $\begin{array}{c}4 \\
17.3 \\
9 \%\end{array}$ & $\begin{array}{c}\mathbf{0} \\
\mathbf{0 \%}\end{array}$ \\
\hline $\begin{array}{l}\text { Using the corpus helped me } \\
\text { organize the essay so that it } \\
\text { seems coherent, organized } \\
\text { and clear. }\end{array}$ & $\begin{array}{c}0 \\
0 \%\end{array}$ & $\begin{array}{c}7 \\
30.43 \\
\%\end{array}$ & $\begin{array}{c}7 \\
30.43 \\
\%\end{array}$ & 5 & $\begin{array}{c}4 \\
17.3 \\
9 \%\end{array}$ & $\begin{array}{c}0 \\
0 \%\end{array}$ \\
\hline
\end{tabular}




\begin{tabular}{|c|c|c|c|c|c|c|}
\hline Statement & SA & $\mathbf{A}$ & D & SD & N/A & $\begin{array}{c}\text { No } \\
\text { response }\end{array}$ \\
\hline $\begin{array}{l}\text { Using the corpus helped me } \\
\text { apply punctuation rules } \\
\text { correctly. }\end{array}$ & $\begin{array}{l}3 \\
13.0 \\
4 \%\end{array}$ & $\begin{array}{c}18 \\
78.26 \\
\%\end{array}$ & $\begin{array}{c}0 \\
0 \%\end{array}$ & $\begin{array}{c}0 \\
0 \%\end{array}$ & $\begin{array}{c}0 \\
0 \%\end{array}$ & $\begin{array}{c}2 \\
8.69 \%\end{array}$ \\
\hline $\begin{array}{l}\text { Using the corpus helped me } \\
\text { correct my spelling mistakes. }\end{array}$ & $\begin{array}{c}4 \\
17.3 \\
9 \%\end{array}$ & $\begin{array}{c}16 \\
69.56 \\
\%\end{array}$ & $\begin{array}{c}2 \\
8.69 \\
\%\end{array}$ & $\begin{array}{c}0 \\
0 \%\end{array}$ & $\begin{array}{c}1 \\
4.3 \\
\%\end{array}$ & $\begin{array}{c}0 \\
0 \%\end{array}$ \\
\hline $\begin{array}{l}\text { Using the corpus helped me } \\
\text { use different styles or modes } \\
\text { of writing (narrative- } \\
\text { descriptive- expository- } \\
\text { argumentative). }\end{array}$ & $\begin{array}{l}2 \\
8.69 \\
\%\end{array}$ & $\begin{array}{c}12 \\
52.17 \\
\%\end{array}$ & $\begin{array}{c}3 \\
13.04 \\
\%\end{array}$ & $\begin{array}{c}1 \\
4.3 \%\end{array}$ & $\begin{array}{l}2 \\
8.69 \\
\%\end{array}$ & $\begin{array}{c}3 \\
13.04 \%\end{array}$ \\
\hline $\begin{array}{l}\text { Using the corpus helped me } \\
\text { summarize the main points of } \\
\text { the essay. }\end{array}$ & $\begin{array}{c}4 \\
17.3 \\
9 \%\end{array}$ & $\begin{array}{c}4 \\
17.39 \\
\%\end{array}$ & $\begin{array}{c}4 \\
17.39 \\
\%\end{array}$ & $\begin{array}{c}3 \\
13.0 \\
\%\end{array}$ & $\begin{array}{c}7 \\
30.3 \\
\%\end{array}$ & $\begin{array}{c}1 \\
4.3 \%\end{array}$ \\
\hline $\begin{array}{l}\text { Using the corpus helped me } \\
\text { proofread or edit to find and } \\
\text { correct deviations in sentence } \\
\text { structure and expressions, } \\
\text { spelling, usage, grammar or } \\
\text { mechanics. }\end{array}$ & $\begin{array}{l}2 \\
8.69 \\
\%\end{array}$ & $\begin{array}{c}19 \\
82.60 \\
\%\end{array}$ & $\begin{array}{c}0 \\
0 \%\end{array}$ & $\begin{array}{c}0 \\
0 \%\end{array}$ & $\begin{array}{l}1 \\
4.3 \\
\%\end{array}$ & $\begin{array}{c}1 \\
4.3 \%\end{array}$ \\
\hline $\begin{array}{l}\text { In general, the corpus was a } \\
\text { useful supplement to EFL } \\
\text { writing. }\end{array}$ & $\begin{array}{c}1 \\
4.3 \\
\%\end{array}$ & $\begin{array}{c}21 \\
91.30 \\
\%\end{array}$ & $\begin{array}{c}0 \\
0 \%\end{array}$ & $\begin{array}{c}0 \\
0 \%\end{array}$ & $\begin{array}{c}0 \\
0 \%\end{array}$ & $\begin{array}{c}1 \\
4.3 \%\end{array}$ \\
\hline $\begin{array}{l}\text { Analyzing the concordance } \\
\text { lines was difficult and took } \\
\text { too much time because there } \\
\text { was a lot of data. }\end{array}$ & $\begin{array}{c}6 \\
26.0 \\
8 \%\end{array}$ & $\begin{array}{c}6 \\
26.08 \\
\%\end{array}$ & $\begin{array}{c}6 \\
26.08 \\
\%\end{array}$ & $\begin{array}{c}2 \\
8.69 \\
\%\end{array}$ & $\begin{array}{l}1 \\
4.3 \\
\%\end{array}$ & $\begin{array}{c}2 \\
8.69 \%\end{array}$ \\
\hline $\begin{array}{l}\text { I intend to use a corpus for } \\
\text { help with my writing in the } \\
\text { future. }\end{array}$ & $\begin{array}{c}3 \\
13.0 \\
4 \%\end{array}$ & $\begin{array}{c}15 \\
65.21 \\
\%\end{array}$ & $\begin{array}{c}2 \\
8.69 \\
\%\end{array}$ & $\begin{array}{c}0 \\
0 \%\end{array}$ & $\begin{array}{c}0 \\
0 \%\end{array}$ & $\begin{array}{c}3 \\
13.04 \%\end{array}$ \\
\hline $\begin{array}{l}\text { I would recommend other } \\
\text { students to use a corpus for } \\
\text { help with their writing. }\end{array}$ & $\begin{array}{c}5 \\
21.7 \\
4 \%\end{array}$ & $\begin{array}{c}14 \\
60.87 \\
\%\end{array}$ & $\begin{array}{l}2 \\
8.69 \\
\%\end{array}$ & $\begin{array}{c}0 \\
0 \%\end{array}$ & $\begin{array}{c}0 \\
0 \%\end{array}$ & $\begin{array}{c}2 \\
8.69 \%\end{array}$ \\
\hline $\begin{array}{l}\text { When I search for information } \\
\text { in the corpus, I usually get the } \\
\text { information that I need. }\end{array}$ & $\begin{array}{c}4 \\
17.3 \\
9 \%\end{array}$ & $\begin{array}{c}16 \\
69.56 \\
\%\end{array}$ & $\begin{array}{c}3 \\
13.04 \\
\%\end{array}$ & $\begin{array}{c}0 \\
0 \%\end{array}$ & $\begin{array}{c}0 \\
0 \%\end{array}$ & $\begin{array}{c}0 \\
0 \%\end{array}$ \\
\hline $\begin{array}{l}\text { Using the corpus has } \\
\text { increased my confidence in } \\
\text { writing in English. }\end{array}$ & $\begin{array}{l}1 \\
4.3 \\
\%\end{array}$ & $\begin{array}{c}20 \\
86.95 \\
\%\end{array}$ & $\begin{array}{c}1 \\
4.3 \%\end{array}$ & $\begin{array}{c}0 \\
0 \%\end{array}$ & $\begin{array}{c}\mathbf{0} \\
\mathbf{0} \%\end{array}$ & $\begin{array}{c}1 \\
4.3 \%\end{array}$ \\
\hline $\begin{array}{l}\text { Using the corpus has } \\
\text { decreased my anxiety about } \\
\text { EFL writing. }\end{array}$ & $\begin{array}{c}2 \\
8.69 \\
\%\end{array}$ & $\begin{array}{c}18 \\
78.26 \\
\%\end{array}$ & $\stackrel{1}{4.3} \%$ & $\begin{array}{c}\mathbf{0} \\
\mathbf{0} \%\end{array}$ & $\begin{array}{c}1 \\
4.3 \\
\%\end{array}$ & $\stackrel{1}{4.3 \%}$ \\
\hline
\end{tabular}

These responses of the participants correspond to the previous results of the quantitative analysis of the EFL writing test and the qualitative analysis of the SSI which showed an improvement in the students' pre-writing skills after implementing the program.

\section{Findings of the Evaluative Questionnaire of the CBP:}

The researchers administered the Evaluative Questionnaire (EQ) after the experiment to examine students' opinions of the CBP. The results of the students' responses to this questionnaire were indicated in the following table: 
Table (3): The results of the students' responses to the $E Q$

\begin{tabular}{|c|c|c|c|c|c|c|}
\hline Statement & SA & A & D & SD & N/A & $\begin{array}{c}\text { No } \\
\text { response }\end{array}$ \\
\hline $\begin{array}{l}\text { The objectives of the } \\
\text { program were identified } \\
\text { from the beginning and } \\
\text { were clearly defined. }\end{array}$ & $\begin{array}{c}6 \\
26.08 \\
\%\end{array}$ & $\begin{array}{c}13 \\
56.5 \%\end{array}$ & $\begin{array}{c}3 \\
13.04 \\
\%\end{array}$ & $\begin{array}{c}\mathbf{0} \\
\mathbf{0} \%\end{array}$ & $\begin{array}{c}\mathbf{0} \\
\mathbf{0} \%\end{array}$ & $\begin{array}{c}1 \\
4.3 \%\end{array}$ \\
\hline $\begin{array}{c}\text { The content of the program } \\
\text { was suitable to achieve its } \\
\text { objectives. }\end{array}$ & $\begin{array}{c}5 \\
21.73 \\
\%\end{array}$ & $\begin{array}{c}\mathbf{1 2} \\
\mathbf{5 2 , 1 7} \\
\%\end{array}$ & $\begin{array}{c}3 \\
13.04 \\
\%\end{array}$ & $\begin{array}{c}0 \\
0 \%\end{array}$ & $\begin{array}{c}\mathbf{0} \\
0 \%\end{array}$ & $\begin{array}{c}3 \\
13.04 \%\end{array}$ \\
\hline $\begin{array}{c}\text { The training material was } \\
\text { logically and sequentially } \\
\text { organized. }\end{array}$ & $\begin{array}{c}3 \\
13.04 \\
\%\end{array}$ & $\begin{array}{c}15 \\
65.21 \\
\%\end{array}$ & $\begin{array}{c}2 \\
8.69 \%\end{array}$ & $\begin{array}{c}1 \\
4.3 \% \\
\end{array}$ & $\begin{array}{c}2 \\
8.69 \\
\%\end{array}$ & $\begin{array}{c}0 \\
0 \%\end{array}$ \\
\hline $\begin{array}{c}\text { The language of the training } \\
\text { material was clear and } \\
\text { comprehensible. }\end{array}$ & $\begin{array}{c}7 \\
30,43 \\
\% \\
\end{array}$ & $\begin{array}{c}11 \\
47.82 \\
\% \\
\end{array}$ & $\begin{array}{c}3 \\
13.04 \\
\%\end{array}$ & $\begin{array}{c}\mathbf{0} \\
\mathbf{0} \%\end{array}$ & $\begin{array}{c}\mathbf{0} \\
\mathbf{0} \%\end{array}$ & $\begin{array}{c}2 \\
8.69 \%\end{array}$ \\
\hline $\begin{array}{l}\text { The activities and exercises } \\
\text { of the program were } \\
\text { interesting, motivating and } \\
\text { suitable for the learners. }\end{array}$ & $\begin{array}{c}4 \\
17.39 \\
\%\end{array}$ & $\begin{array}{c}11 \\
47.82 \\
\%\end{array}$ & $\begin{array}{c}4 \\
17.39 \\
\%\end{array}$ & $\begin{array}{c}1 \\
4.3 \%\end{array}$ & $\begin{array}{c}2 \\
8.69 \\
\%\end{array}$ & $\begin{array}{c}1 \\
4.3 \%\end{array}$ \\
\hline $\begin{array}{l}\text { The content of the program } \\
\text { corresponded with the } \\
\text { professional needs of the } \\
\text { learners. }\end{array}$ & $\begin{array}{c}2 \\
8.69 \%\end{array}$ & $\begin{array}{c}15 \\
65.21 \\
\%\end{array}$ & $\begin{array}{c}3 \\
13.04 \\
\%\end{array}$ & $\begin{array}{c}1 \\
4.3 \%\end{array}$ & $\begin{array}{c}2 \\
8.69 \\
\%\end{array}$ & $\begin{array}{c}1 \\
4.3 \%\end{array}$ \\
\hline $\begin{array}{l}\text { The pace of instruction was } \\
\text { suitable for the learners } \\
\text { (neither too fast nor too } \\
\text { slow). }\end{array}$ & $\begin{array}{c}5 \\
21.73 \\
\%\end{array}$ & $\begin{array}{c}14 \\
60.86 \\
\%\end{array}$ & $\begin{array}{c}2 \\
8.69 \%\end{array}$ & $\begin{array}{c}2 \\
8.69 \%\end{array}$ & $\begin{array}{c}\mathbf{0} \\
\mathbf{0} \%\end{array}$ & $\begin{array}{c}0 \\
0 \%\end{array}$ \\
\hline $\begin{array}{l}\text { The general atmosphere of } \\
\text { the program was } \\
\text { encouraging and interesting. }\end{array}$ & $\begin{array}{c}8 \\
34.78 \\
\% \\
\end{array}$ & $\begin{array}{c}11 \\
47.82 \\
\% \\
\end{array}$ & $\begin{array}{c}3 \\
13.04 \\
\% \\
\end{array}$ & $\begin{array}{c}\mathbf{0} \\
\mathbf{0} \%\end{array}$ & $\begin{array}{c}\mathbf{0} \\
0 \%\end{array}$ & $\begin{array}{c}1 \\
4.3 \%\end{array}$ \\
\hline $\begin{array}{c}\text { The learning outcomes of } \\
\text { the program met learners' } \\
\text { expectations. }\end{array}$ & $\begin{array}{c}3 \\
13.04 \\
\% \\
\end{array}$ & $\begin{array}{c}13 \\
56.5 \% \\
\end{array}$ & $\begin{array}{c}3 \\
13.04 \\
\%\end{array}$ & $\begin{array}{c}2 \\
8.69 \%\end{array}$ & $\begin{array}{l}1 \\
4.3 \\
\%\end{array}$ & $\begin{array}{c}1 \\
4.3 \%\end{array}$ \\
\hline $\begin{array}{l}\text { There were some topics } \\
\text { there were not covered well } \\
\text { and needed more training. }\end{array}$ & $\begin{array}{c}0 \\
0 \%\end{array}$ & $\begin{array}{c}5 \\
21.73 \\
\%\end{array}$ & $\begin{array}{c}8 \\
34.78 \\
\%\end{array}$ & $\begin{array}{c}8 \\
34.78 \\
\%\end{array}$ & $\begin{array}{l}1 \\
4.3 \\
\%\end{array}$ & $\begin{array}{c}1 \\
4.3 \%\end{array}$ \\
\hline $\begin{array}{l}\text { The assessment tools } \\
\text { measured the intended } \\
\text { skills that the program } \\
\text { aimed to develop. }\end{array}$ & $\begin{array}{l}12 \\
52.17 \\
\%\end{array}$ & $\begin{array}{c}8 \\
34.78 \\
\%\end{array}$ & $\begin{array}{c}1 \\
4.3 \%\end{array}$ & $\begin{array}{c}0 \\
0 \%\end{array}$ & $\begin{array}{c}\mathbf{0} \\
\mathbf{0} \%\end{array}$ & $\begin{array}{c}2 \\
8.69 \%\end{array}$ \\
\hline $\begin{array}{l}\text { The program included } \\
\text { opportunities for the } \\
\text { learners to express their } \\
\text { points of view freely. }\end{array}$ & $\begin{array}{l}9 \\
39.13 \\
\%\end{array}$ & $\begin{array}{l}10 \\
43.47 \\
\%\end{array}$ & $\begin{array}{c}3 \\
13.04 \\
\%\end{array}$ & $\begin{array}{c}1 \\
4.3 \%\end{array}$ & $\begin{array}{c}\mathbf{0} \\
0 \%\end{array}$ & $\begin{array}{c}0 \\
0 \%\end{array}$ \\
\hline $\begin{array}{l}\text { The time schedule of the } \\
\text { program was presented to } \\
\text { the learners from the } \\
\text { beginning. }\end{array}$ & $\begin{array}{c}3 \\
13.04 \\
\%\end{array}$ & $\begin{array}{l}15 \\
65.21 \\
\%\end{array}$ & $\begin{array}{c}2 \\
8.69 \%\end{array}$ & $\begin{array}{c}1 \\
4.3 \%\end{array}$ & $\begin{array}{c}\mathbf{0} \\
0 \%\end{array}$ & $\begin{array}{c}2 \\
8.69 \%\end{array}$ \\
\hline $\begin{array}{l}\text { The program was } \\
\text { implemented within the } \\
\text { presented time schedule. }\end{array}$ & $\begin{array}{c}\mathbf{0} \\
\mathbf{0} \%\end{array}$ & $\begin{array}{c}3 \\
13.04 \\
\%\end{array}$ & $\begin{array}{c}13 \\
56.5 \%\end{array}$ & $\begin{array}{c}5 \\
8.69 \%\end{array}$ & $\begin{array}{c}2 \\
8.69 \\
\%\end{array}$ & $\begin{array}{c}\mathbf{0} \\
\mathbf{0 \%}\end{array}$ \\
\hline $\begin{array}{c}\text { The time allotted for each } \\
\text { session was suitable for the } \\
\text { presented content. }\end{array}$ & $\begin{array}{c}\mathbf{0} \\
0 \%\end{array}$ & $\begin{array}{c}4 \\
17.39 \\
\%\end{array}$ & $\begin{array}{c}8 \\
34.78 \\
\%\end{array}$ & $\begin{array}{c}9 \\
39.13 \\
\%\end{array}$ & $\begin{array}{c}2 \\
8.69 \\
\%\end{array}$ & $\begin{array}{c}\mathbf{0} \\
0 \%\end{array}$ \\
\hline $\begin{array}{l}\text { The place of training was } \\
\text { suitable and contained the } \\
\text { required tools for } \\
\text { implementing the program. }\end{array}$ & $\begin{array}{c}4 \\
17.39 \\
\%\end{array}$ & $\begin{array}{c}\mathbf{1 2} \\
\mathbf{5 2 , 1 7} \\
\%\end{array}$ & $\begin{array}{c}3 \\
13.04 \\
\%\end{array}$ & $\begin{array}{c}2 \\
8.69 \%\end{array}$ & $\begin{array}{c}1 \\
4.3 \\
\%\end{array}$ & $\begin{array}{c}1 \\
4.3 \%\end{array}$ \\
\hline $\begin{array}{l}\text { The program achieved its } \\
\text { stated objectives. }\end{array}$ & $\begin{array}{c}4 \\
17.39 \\
\% \\
\end{array}$ & $\begin{array}{c}13 \\
56.5 \%\end{array}$ & $\begin{array}{c}2 \\
8.69 \%\end{array}$ & $\begin{array}{c}0 \\
0 \%\end{array}$ & $\begin{array}{c}2 \\
8.69 \\
\%\end{array}$ & $\begin{array}{c}2 \\
8.69 \%\end{array}$ \\
\hline
\end{tabular}


From the preceding table, it can be concluded that most of the students (77\%) were satisfied with the program and this was apparent in their responses to the first part of the EQ. This satisfaction was indicated by their contentment of the content of the program (statement, 2), the language of the training material (statement, 4), the activities and exercises (statement, 5), the pace of instruction (statement, 7), the general atmosphere of the program (statement, 8), the learning outcomes (statement, 9) and the assessment tools used to measure the intended skills (statement, 11).

\subsection{Discussion:}

Based on the results of both quantitative and qualitative analysis of data it can be concluded that the CBP was effective in developing the participants of the present study's EFL writing skills. The reasons that justified the results of the present study include firstly the nature of corpus itself. The corpus approach changed the traditional "three Ps" (Presentation, Practice and Production) approach to teaching with a more exploratory approach of "three Is" (Illustration, Interaction and Induction). Therefore, the learning becomes more individualized and student-centered. Moreover, the corpus allows students to encounter 'real or authentic language' rather than made-up examples. Similarly, with the corpus the students benefit more from a "learning by discovery" approach since this encourages learners to follow their own interests whilst developing their capacities and competences. Also, in corpus-based language learning both inductive and deductive learning approaches are included. Finally, corpus consultation enhances learner autonomy. All these advantages contributed to achieving the goals of the present study.

These results are consistent with previous studies which proved the great contribution of the corpus in developing EFL writing skills such as: (Kaur \& Hegelheimer, 2005; Choi, 2007; Vannestål \& Lindquist, 2007; Tankó, 2008 ; Yoon, 2010; Sahillioglu; Sahinkayasi \& Sahinkayasi, 2012). 


\subsection{Conclusion:}

Based on the results of statistical analysis of data (quantitatively and qualitatively), it can be concluded that the participants of study's EFL writing skills were developed as a result of participating in the CBP. Accordingly, the CBP can be estimated as being effective in achieving the goals of the present study.

\subsection{Recommendations of the study:}

In the light of the results of the present study, the following recommendations can be deduced:

1. The content presented on the text books should be based on authentic rather invented or made-up examples.

2. Teacher education programs should include a separate course on corpus linguistics due to its emphasized effect on developing EFL skills in general and EFL writing skills in particular.

3. Teaching should be turned from being teacher-centered to learner-oriented in which learners become more involved in and responsible for their learning and become self-autonomous.

\subsection{Suggestions of further research:}

Based on the findings of the present study, the researchers suggest conducting further studies to:

1. Investigate the effect of the Corpus Approach on developing EFL writing skills among other categories of EFL learners other than the participants of study.

2. Investigate the impact of the Corpus Approach on developing other language skills such as reading.

3. Test the effect of the Corpus Approach on developing EFL learners' motivation and attitudes towards EFL learning.

4. Investigate the effect of the Corpus Approach on developing EFL in-service teachers' language teaching skills. 
5. Re-conduct other studies to confirm the results of the present study.

6. Investigate the effectiveness of other technology applications on the EFL writing skills among EFL learners.

7. Compare the effect of technology-based approaches versus traditional approaches to develop EFL writing skills.

\section{References:}

Abdel-Hack, E. M. (2002). The effectiveness of Task-Based Learning Approach on Students' written Production. Paper presented at the $22^{\text {nd }}$ CDELT National symposium on English Language Teaching. Ain Shams University, Egypt.

Abdel-Hack, E.M. (2009). Fostering critical thinking dispositions and writing performance using journal-writing technique. In, A.A. El-Marasafy and E.M. Abdel-Hack (Eds), New Trends in Teaching Reading and Writing, (pp.333-367). Benha, Egypt: Middle East Center for Educational Services.

Abdel-Maksoud, M.S. (2007). The effectiveness of a dialogue Journal writing approach in developing EFL writing skills and attitudes among secondary school students. Unpublished MA thesis, Faculty of Education, Benha University.

Alshumaimeri, Y. (2011). The effects of wikis on foreign language students writing performance. Procedia - Social and Behavioral Sciences, 28: 755-763.

Balunda, S. (2009). Teaching Academic Vocabulary with Corpora : Student Perceptions of Data-Driven Learning. An unpublished Master of Arts thesis. (Available online at:https://scholarworks.iupui.edu/bitstream/handle/1805/2 049/Balunda\%20MA\%20Thesis\%20Teaching\%20Academic \%20Vocabulary\%20with\%20Corpora.pdf) (Retrieved on: $12 / 7 / 2013)$.

Bello, T. (1997). Improving ESL Learner's Writing Skills. (An online ERIC database full text No.ED409746).

Bernardini, S. (2004). Corpora in the classroom: An overview and some reflections on future developments. In J. McH. Sinclair 
(ed). How to Use Corpora in Language Teaching (Pp.15-36). Amsterdam/Philadelphia: John Benjamins Publishing Company.

Braun, S. (2005). From pedagogically relevant corpora to authentic language learning contents.ReCALL17 (1): 47-64.

Breyer, Y. (2009). Learning and teaching with corpora: reflections by student teachers. Computer Assisted Language Learning, 22(2): 153-172.

Carter, R. and McCarthy, M. (1995). Grammar and the spoken language. Applied Linguistics, 16(2): 141-158.

Chambers, A. and O'Sullivan, I. (2004). Corpus Consultation and advanced learners' writing skills in French, ReCALL, 16(1), 158-72.

Charles, M. (2007). Reconciling top-down and bottom-up approaches to graduate writing: Using a corpus to teach rhetorical functions. Journal of English for Academic Purposes, 6:289-302.

Choi, (2007). A Corpus-Based Discourse Analysis of Korean Discourse Markers: an Analysis of Spoken and Written Use. $D A I-A, 69 / 02$.

Cresswell, A. (2007). Getting to 'know' connectors? Evaluating data-driven learning in a writing skills course. In E. Hidalgo; L. Quereda and S. Juan (Eds.), Corpora in the foreign language classroom (Pp. 267-287).Amsterdam, Netherlands: Rodopi.

Crompton, P. (2005). 'Where', 'In Which', and 'In That': A CorpusBased Approach to Error Analysis. Regional Language Centre Journal, 36(2):157-167.

Cumming, A. (2006). Teaching writing: Orienting activities to students' goals. In E. Uso'-Juan and A. Martı'nez-Flor (Eds), Current Trends in the Development and Teaching of the Four Language Skills (pp.473-491), Berlin: Mouton de Gruyter.

DeDeyn, R. (2011). Student Identity, Writing Anxiety, and Writing Performance: A Correlational Study. MAI, 49/06. Eggenschwiler, J. and Biggs, E. (2001). Writing: Grammar, Usage, and Style. New York: Hungry Minds, Inc. 
El-Marsafy, A.A. (2009). Utilizing the process writing approach to activate EFL prospective teacher's content and organization writing skills. In, A.A. El-Marsafy and E.M. Abdel-Hack (Eds), NEW TRENDS IN TEACHING READING AND WRITING, (pp.161-210). Benha, Egypt: Middle East Centre for Educational Services.

Elola, I. and Oskioz, A. (2010). Collaborative Writing: Fostering Foreign Language and Writing Conventions Development. Language Learning \&Technology, 14(3):51-71

El-Serafy, R. A. (2008). The effect of using text-based approach on EFL writing apprehension and accuracy among prep school students. Unpublished M.A. thesis, Faculty of Education, Benha University.

Erkan, D. and Saban, A. (2011). Writing Performance Relative to Writing Apprehension, Self-Efficacy in Writing, and Attitudes towards Writing: A Correlational Study in Turkish Tertiary-Level EFL. The Asian EFL Journal Quarterly, 13(1):163-191.

Fageeh, A. (2011). EFL Learners' Use of Blogging for Developing Writing skills and Enhancing Attitudes towards English learning: An Exploratory Study. Journal of Language and Literature, 2(1).

Farr, F. (2008). Evaluating the Use of Corpus-Based Instruction in a Language Teacher Education Context: Perspectives from the Users. Language Awareness, 17(1): 25-43.

Finn, S. and Inman, J. (2004). Digital unity and digital divide: Surveying alumni to study the effects of a campus laptop initiative. Journal of Research on Technology in Education, 36(3): 297-317.

Flowerdew, L. (1998). Corpus-linguistic techniques applied to textlinguistics. System, 26: 541-552.

Fulwiler, T. (2002). College Writing: A Personal Approach to Academic Writing Third Edition. Portsmouth, NH: Boynton/Cook Publishers, Inc.

Garner, J. and Nelson, R. (2011). Does Data-Driven Learning Lead to Better Academic Writing?. MAI, 49/06. 
Gaskell, D. and Cobb, T. (2004). Can learners use concordance feedback for writing errors? System, 32(3): 301-319.

Godwin-Jones, B. (2001). Tools and trends in corpora use for teaching and learning. Language Learning \& Technology, 5(3): 7-12.

Gömleksiz, M. (2004). Use of Education Technology in English Classes. The Turkish Online Journal of Educational Technology - TOJET, 3(2):71-77.

Granath, S. (2009). Who benefits from learning how to use corpora? In K. Aijmer (Ed). Corpora and language teaching (Pp 47-65). Amsterdam: John Benjamins Publishing Company.

Harmer, J. (2004). How to Teach Writing. London: Pearson Education Ltd.

Helwa, H. S. (2013) The Effectiveness of a Self-Autonomy Based Program in Developing EFL Student Teachers' Communicative Competence. Unpublished $\mathrm{PhD}$ thesis, Faculty of Education, Benha University.

Hunston, S. (2002). Corpora in applied linguistics. Cambridge: Cambridge University Press.

Hyland, K. (2003). Second language writing. Cambridge, UK: Cambridge University Press.

Hyland, K. (2006). English for academic purposes: An advanced resource book. London: Rutledge.

Ismail, S.; Al-Awidi, H. and Almekhlafi, A. (2012).Employing Reading and Writing Computer-Based Instruction in English as a Second Language in Elementary Schools. International Journal of Business and Social Science, 3(12) [Special Issue]:265- 274.

Jahin, J. H. (2012). The Effect of Peer Reviewing on Writing Apprehension and Essay Writing Ability of Prospective EFL Teachers. Australian Journal of Teacher Education, 37(11):60-84.

Johansson, S. (2004). Some thoughts on Corpora and SecondLanguage Acquisition. In K. Aijmer (ed). Corpora and Language Teaching, (pp.33-44). Amsterdam and Philadelphia, PA: John Benjamins Publishing Company. 
Kaur, J. and Hegelheimer, V. (2005). ESL Students' Use of Concordance in the Transfer of Academic Word Knowledge: An exploratory study. Computer Assisted Language Learning, 18(4):287-310.

Kim, C-K. (2009). Personal pronouns in English and Korean texts: A corpus-based study in terms of textual interaction. Journal of Pragmatics, 41: 2086-2099.

Kiser, A. and Craven, A. (2009). What Students, Professors, and IT Staff Had to Say About the Laptop Program at a Four-Year Hispanic Serving Institution. Journal of Literacy and Technology, 10(2): 39-63.

Koo, K. (2006). Effects of Using Corpora and Online Reference Tools on Foreign Language Writing: A Study of Korean Learners of English as a Second Language. DAI-A, 67/03.

Koosha, M. and Jafarpour, A. (2006). Data-driven learning and teaching collocation of prepositions: the case of Iranian EFL adult learners. Asian EFL Journal Quarterly, 8 (4): 192-209.

Kutlu, O. (2013). Using technology for developing writing in an ESP class. Procedia - Social and Behavioral Science,70: 267271.

Lee, K-W. (2000b). English teachers' barriers to the use of computer-assisted language learning. Internet TESOL Journal, 6 (12).

Mekheimer, M. (2005). Effects of Internet-based Instruction, Using Webquesting and Emailing on Developing Some Essay Writing Skills in Student Teachers. Unpublished PhD thesis, Cairo University.

Miyazoe, T. Anderson, T. (2010). Learning outcomes and students' perceptions of online writing: Simultaneous implementation of a forum, blog, and wiki in an EFL blended learning setting. System, 38: 185-199.

Mozaheb, M.; Seifoori, Z. and Beigi, A. (2013). Effective Iranian EFL writing teachers (a technology-based framework). Procedia - Social and Behavioral Sciences, 70:18-27.

Nam, D. (2010). Productive Vocabulary Knowledge and Evaluation of ESL Writing in Corpus-Based Language Learning. DAI-A, 71/09. 
Noytim, U. (2010). Weblogs enhancing EFL students' English language learning. Procedia-Social and Behavioral Sciences, 2:1127-1132.

O'Keeffe, A. and McCarthy, M. (eds) (2010). The Routledge handbook of corpus linguistics. London/New York: Routledge.

O'Sullivan, I. and Chambers, A. (2006). Learners' writing skills in French: Corpus consultation and learner evaluation. Journal of Second Language Writing, 15(1): 49-68.

Olshtain, E. (2001). Functional tasks for mastering the mechanics of writing and going just beyond. In, Marianne Celce-Murcia (ed.). Teaching English as a second or foreign language (pp.207-217). Boston: Heinle and Heinle.

Paulus, T. and Nakamichi, Y. (2002). The impact of CALL instruction on classroom computer use: A foundation for rethinking technology in teacher education. Language Learning and Technology, 6 (3): 108-126.

Pennington, M. C. (2003). The impact of computer in second language writing. In B. Kroll (Eds.). Exploring the dynamics of second language writing (pp. 287-310). Cambridge: Cambridge University Press.

Redrupová, V. (2009). An Examination of the Use of Corpora and Concordances in Language Teaching and Learning and its Implications for Syllabus Design in Secondary Schools. Unpublished Master's Diploma Thesis. (Available online at: is.muni.cz/th/156173/ff.../Redrupova_MA_Thesis.pdf)

(Retrieved on: 12/7/2013).

Römer, U. (2009). Corpus research and practice: What help do teachers need and what can we offer? In K. Aijmer (ed). Corpora and language teaching (Pp. Pp83-98). Amsterdam: John Benjamins Publishing Company.

Sahillioglu, F.; Sahinkayasi, Y. and Sahinkayasi, H. (2012). Effectiveness of Two Corpus Tools on Turkish Students' Learning English Grammar. E-Journal of New World Sciences Academy, 7(1): 230-240. 
Samburskiy, D. (2014). Corpus-Informed Pedagogical Grammar of English: Pros and Cons. Procedia - Social and Behavioral Sciences, 154: 263 - 267.

San, Y. (2007). The efficacy of computer assisted language learning in fostering autonomous learning among upper secondary school students. Internet Journal of e-Language Learning \& Teaching, 4:32-45.

Saunders, P. (2010). Academic Writing: At the Interface of Corpus and Discourse. System, 38: 499-511.

Sauro, S. (2009). Computer-Mediated Corrective Feedback and the Development of L2 Grammar. Language Learning \& Technology, 13(1):96-120

Shang, H.-F (2013b). Factors Associated With English As A Foreign Language University Students Writing Anxiety. International Journal of English Language Teaching, 1(1):112.

Sova, D. (2004). Writing Clearly a Self-Teaching Guide. New Jersey: John Wiley \& Sons, Inc.

Tankó, G. (2008). The use of adverbial connectors in Hungarian university students' argumentative essays. In John $\mathrm{McH}$. Sinclair (ed). How to Use Corpora in Language Teaching (Pp. 157-181). Amsterdam/Philadelphia: John Benjamins Publishing Company.

Thornbury, S. (2010). What can a corpus tell us about discourse?. In A. O'Keeffe and M. McCarthy (eds), The Routledge handbook of corpus linguistics (Pp270-287). London: Routledge.

Tseng, Y.-C. and Liou, H.-C. (2006).The effects of online conjunction materialson college EFL students' writing. System, 34: 270-283.

Tsou, W.; Wang, W. and Li, H. (2002). How computers facilitate English foreign language learners acquire English abstract words. Computers \& Education, 39 (4):415-428.

Vannestål, M. and Lindquist, H. (2007). Learning English grammar with a corpus: Experimenting with concordancing in a university grammar course. ReCALL, 19(3):329-350. 
Wen-juan, S. and Hong-bo, Z. (2011). Scientific Writing or Creative Writing: A Corpus Investigation. US-China Foreign Language, 9(5): 271-279.

Yang, Y-F. and Meng, W-T. (2013). The Effects of Online Feedback Training on Students' Text Revision. Language Learning \& Technology, 17(2): 220-238.

Yanguas, I. (2009). Multimedia Glosses and Their Effect on L2 Text Comprehension and Vocabulary Learning. Language Learning \& Technology, 13(2): 48-67.

Yeh, Y.; Liou, H-C. and Li, Y-H. (2007). Online Synonym Materials and Concordancing for EFL College Writing. Computer Assisted Language Learning, 20(2):131-152.

Yoon, C. (2010). Concordancing in L2 writing class: An overview of research and issues. Journal of English for Academic Purposes. 10: 130-139

Yoon, H. (2005). An investigation of students' experience with corpus technology in second language academic writing. $D A I-A, 66 / 01$, p. 121.

Yoon, H. (2008). More Than a Linguistic Reference: The Influence of Corpus Technology on L2 Academic Writing. Language Learning \& Technology, 12 (2): 31-48.

Yoon, H. and Hirvela, A. (2004). ESL student attitudes toward corpus use in L2 writing. Journal of Second Language Writing, 13: 257-283.

Zacharias, N. (2007). Teacher and student attitudes toward teacher feedback. RELC Journal, 38:38-57.

Zhu, W. (2004). Faculty views on the importance of writing, the nature of academic writing, and teaching and responding to writing in the disciplines. Journal of Second Language Writing, 13:29-48. 
